\title{
Embryotoxic and Teratogenic Potentials of Salacia lehmbachii in Rats
}

\author{
${ }^{1}$ G.A. Essiet, ${ }^{2}$ G. C. Akuodor and ${ }^{1}$ A.D. Essien \\ ${ }^{I}$ Department of Pharmacology, Faculty of Basic Medical Sciences, College of Medical Sciences, University of \\ Calabar, Calabar, Nigeria. \\ ${ }^{2}$ Department of Pharmacology and Therapeutics, Faculty of Medicine, Ebonyi State University, Abakaliki, \\ Nigeria.
}

\begin{abstract}
Use of herbal remedies in pregnancy may be deleterious to both mother and fetus. Against this background, aqueous and ethanol root bark extracts of Salacia lehmbachii, widely used herbal remedies for treatment of malaria in some localities were evaluated for embryotoxicity and teratogenicity in albino rats. One hundred and five pregnant rats weighing 170-180g were assigned 7 groups ( $n=15)$, labeled Control, 1-6. Control rats had $2 \mathrm{~mL}$ of distilled water. Groups 1, 2 and 3 received 250, 500 and 750mg/kg body weight of aqueous extract respectively while groups 4, 5 and 6 had similar doses of ethanol extract. Administration was orally on days 1 to 6 of gestation for implantation studies and days 7 to 15 for teratogenicity. The rats were observed daily for lethality, abnormal behaviour and vaginal bleeding. Their weights, food and water intakes were recorded. Cesarean sections were performed on day 20 of gestation to remove their uterine horns and implantations, resorptions, live and dead fetuses recorded. The weight and crown rump lengths of live fetuses were obtained and the placentas weighed and examined along with the litters for anomalies. There were no signs of maternal toxicity, miscarriages and dead fetus. Number of live fetuses in treated rats were similar to control just like litter weights, crown rump lengths and placental weight. There were no external anomalies on the fetuses and placenta. The extracts at the doses used in the study are relatively safe for pregnant rats and developing fetuses.
\end{abstract}

Keywords: Embryotoxicity, pregnancy, teratogenicity, root bark, Salacia lehmbachii.

\section{Introduction}

The use of herbal remedies in primary health care continues to gain popularity especially in developing countries. Herbal medicines contain active ingredients of whole plants or parts thereof perceived to have therapeutic benefits [1]. Although these medicines are generally considered safe, in reality it is known that the active components may cause serious adverse effects especially as they are not subjected to rigorous scrutiny for safety as is the case with conventional medicines [2,3]. The risk of herb induced adverse effects is higher in people who are already prone to adverse reactions to conventional pharmacological preparations. Such persons include pregnant women, fetuses, children, lactating mothers and the elderly [4-7]. Pregnancy is associated with marked physiological alterations which perhaps make pregnant women more susceptible to certain diseases like malaria [8,9]. The use of medications during pregnancy may expose the developing fetus to risks like miscarriage, intrauterine growth retardation, malformations and mortality. In this respect, the historical saga of thalidomide, a sedative used in the treatment of hyperemesis gravidarum, but later found to be responsible for a string of birth defects readily comes to mind [10-13]. Many herbal remedies have been reported to impair fetal development following usage in pregnancy [14-22].

Salacia lehmbachii (Family, Celastraceae) is a popular medicinal plant used by locals in some parts of Southeastern Nigeria and Cameroun particularly the Bakassi forest reserves, for the treatment of febrile illnesses like malaria. Pregnant women are vulnerable to malaria which is endemic in these parts [23]. The plant is called 'eba-enang-enang' by the peoples of Akwa Ibom and Cross River States and 'ara-mmanu'by the Igbos, all of Nigeria. Earlier work from this department had shown the median lethal dose $\left(\mathrm{LD}_{50}\right)$ of the root bark extract of the plant in albino rats to be above $5000 \mathrm{mg} / \mathrm{kg}$, while the chemical constituents were alkaloids, glycosides, flavonoids, tannins, saponins and polyphenols [24]. Biological effects of the plant include analgesia and antiinflammation [24], antipyresia [25], nephroprotection [26], anti-abortifacient action [27], antioxidant action [28], inhibition of male sex hormones [29] and antifertility in male rats [30]. The hepatotoxic and hematotoxic potentials of the plant have also been evaluated [31,32] and the antimalarial action of the plant has been established (Essien AD, University of Calabar, Calabar, Nigeria, unpublished results). This study aimed to evaluate the embryotoxic and teratogenic potential of aqueous and ethanol extracts of the root bark of the plant in albino rats. 


\subsection{Collection and identification of plant material}

\section{Materials And Methods}

The roots of Salacia lehmbachii were purchased from a local market in Calabar, capital of Cross River State, Nigeria. The plant was authenticated by the department of Botany of the University of Calabar and a Specimen with Voucher number 688 deposited in the department for reference.

\subsection{Preparation of the extract}

The roots were washed with water to remove dirt and dried in their lengths in an electric oven, thermostatically controlled at $40^{\circ} \mathrm{C}$, for 12 hours. The root bark powder of the plant was obtained and stored following an earlier described method [29]. The dry aqueous and ethanol extracts were derived from a twostaged Soxhlet extraction of the root bark powder following the methods of Essiet et al [31]. The solid extract which formed the yield was weighed and preserved in a clean and dry container until required for the experiments. The extracts were constituted in distilled water to give the doses required for the study.

\subsection{Experimental animals}

One hundred and five pregnant rats weighing 170-180g purchased from the Animal house, Department of Pharmacology, University of Calabar were used for this study. They were housed in well ventilated plastic cages, each containing fifteen rats. Each rat was properly identified by branding with dilute picric acid. The animals were acclimatized for seven days to normal laboratory conditions (relative humidity: 50 $\pm 5 \%$; temperature: $28 \pm 2^{\circ} \mathrm{C}$ and 12 hours of light-dark cycle) before the start of the experiment and maintained at the same conditions throughout the study period. They were fed with standard rat chow (Agro-Feeds, Calabar) and water (Water board, Calabar) ad libitum. The guidelines on Care and Use of Laboratory animals were scrupulously observed [33].

\subsection{Animal grouping and treatment}

Sexually mature female rats were paired with their male counterparts and confined in a cage overnight for mating. The following day was designated day 1 of pregnancy if the dams had vaginal seminal plugs or spermatozoa were found in their vaginal smears on microscopic examination [34]. Pregnant rats were weighed and randomly assigned to 7 groups $(\mathrm{n}=15)$, labeled Control, 1- 6. Control rats were administered $2 \mathrm{~mL}$ of distilled water, the vehicle for the extract. Groups 1,2 and 3 received 250,500 and $750 \mathrm{mg} / \mathrm{kg}$ body weight of aqueous extract respectively while groups 4, 5 and 6 were treated with 250,500 and $750 \mathrm{mg} / \mathrm{kg}$ body weight of ethanol extract respectively. Administration was via a gastric cannula from day 1 to 6 of gestation for implantation studies[35] and day 7 to 15 of gestation for studies on organogenesis and possible terratogenicity $[36,37]$.

To evaluate the extracts for maternal toxicity, the rats in each study group were observed daily for certain changes (lethality, abnormal behaviour, vaginal bleeding) and their weights taken on the 1st, 7th, 14th and 20th day of gestation using an electronic weighing balance. Food and water intake by the pregnant rats were monitored using the periodic manual recordings[38]. Laparotomy was performed under chloroform inhalation anaesthesia on the $20^{\text {th }}$ day of gestation to remove the rat uteri [37]. The uterine horns were then opened up to count the numbers of fetuses (both live and dead), resorption sites and implantations. The ovaries were retrieved and the corpora lutea within them counted. Live fetuses were weighed, their crown-rump lengths measured after which they were examined for gross malformations. The placentas were equally weighed and examined for abnormalities.

The data obtained above were processed to obtain the following parameters namely [36-38]: i) Implantation index $=$ total number of implantation sites / number of corpora lutea $\mathrm{x} 100$, ii) Resorption index $=$ total number of resorption sites / total number of implantation sites x100, iii) Preimplantation loss = number of corpora lutea - number of implantations / number of corpora lutea x100 and iv) Post implantation loss $=$ number of implantations - number of live fetuses / number of implantations x 100.

\subsection{Statistical Analysis}

The Statistical Package for Social Sciences (SPSS) version 20 was used to analyse data obtained from the study and values obtained from descriptive statistics expressed as means \pm standard error of mean (SEM). Turkey's multiple comparison post hoc testing was carried out to compare the different study groups. Where applicable students t-test was used to compare differences between treated and control groups for significance at discreet dose levels. Differences were considered significant at $\mathrm{P}$ values of $P<0.05$. 


\section{Results}

The rats gained comparable weight during the different periods of gestation assessed (TABLE 1). During the period of experimentation, there were no maternal deaths, no toxic clinical signs and the treated pregnant dams consumed as much food and water per day as control rats (TABLE 2). There was no abortion as the control and treated pregnant rats carried their pregnancies to term when they were sacrificed.

There were no resorption sites, resulting in a nil value of resorption index. Other implantation indices (implantation index, pre-implantation loss and post-implantation loss) were insignificantly $(\mathrm{p}>0.05)$ different in treated rats compared to control (TABLE 3). There was no dead fetus in both control and treated rats and the difference between the number of live fetuses delivered by treated rats and those delivered by control rats was not statistically significant $(\mathrm{p}>0.05)$. The fetal indices namely fetal weight, crown rump length and placental weight were dose dependently and insignificantly $(p>0.05)$ increased in aqueous extract-treated rats compared to control. The above indices were reduced in rats treated with the ethanol extract and the reduction was significant $(p<0.5)$ only with the highest dose of $750 \mathrm{mg} / \mathrm{kg}$ (TABLE 4$)$. There were no gross abnormalities in the fetuses and placentas of treated and control rats (TABLE 4).

Table 1. Body weight in Control and Treated pregnant rats

\begin{tabular}{|c|c|c|c|c|}
\hline \multirow{2}{*}{$\begin{array}{l}\text { Study groups } \\
(\mathrm{n}=15)\end{array}$} & \multicolumn{4}{|c|}{ Maternal weight $(\mathrm{g}) /$ days of pregnancy } \\
\hline & Day 1 & Day7 & Day14 & \\
\hline Control & $\begin{array}{c}175.44 \pm 10.09 \\
(0 \%)\end{array}$ & $\begin{array}{c}189.04 \pm 11.16 \\
(7.75 \%)\end{array}$ & $\begin{array}{c}220.70 \pm 15.02 \\
(18.05 \%)\end{array}$ & $\begin{array}{c}276.68 \pm 12.33 \\
(31.91 \%)\end{array}$ \\
\hline $1(250 \mathrm{mg} / \mathrm{kg}$ of ASL) & $\begin{array}{c}177.12 \pm 9.77 \\
(0 \%)\end{array}$ & $\begin{array}{c}190.82 \pm 10.14 \\
(7.73 \%)\end{array}$ & $\begin{array}{c}222.60 \pm 14.22 \\
(17.94 \%)\end{array}$ & $\begin{array}{c}279.13 \pm 12.03 \\
(31.92 \%)\end{array}$ \\
\hline $2(500 \mathrm{mg} / \mathrm{kg}$ of ASL) & $\begin{array}{c}172.72 \pm 6.18 \\
(0 \%)\end{array}$ & $\begin{array}{l}185.88 \pm 10.45 \\
(7.62 \%)\end{array}$ & $\begin{array}{c}217.09 \pm 13.15 \\
(18.07 \%)\end{array}$ & $\begin{array}{c}272.25 \pm 12.41 \\
(31.94 \%)\end{array}$ \\
\hline $3(750 \mathrm{mg} / \mathrm{kg}$ of ASL) & $\begin{array}{c}170.92 \pm 5.77 \\
(0 \%)\end{array}$ & $\begin{array}{l}184.32 \pm 11.61 \\
(7.84 \%)\end{array}$ & $\begin{array}{c}215.27 \pm 14.05 \\
(18.11 \%)\end{array}$ & $\begin{array}{c}269.93 \pm 13.12 \\
(31.98 \%)\end{array}$ \\
\hline $4(250 \mathrm{mg} / \mathrm{kg}$ of ESL) & $\begin{array}{c}179.12 \pm 9.13 \\
(0 \%)\end{array}$ & $\begin{array}{l}193.11 \pm 11.31 \\
(7.81 \%)\end{array}$ & $\begin{array}{c}225.56 \pm 9.21 \\
(18.12 \%)\end{array}$ & $\begin{array}{c}282.54 \pm 10.41 \\
(31.81 \%)\end{array}$ \\
\hline $5(500 \mathrm{mg} / \mathrm{kg}$ of ESL) & $\begin{array}{c}176.22 \pm 11.11 \\
(0 \%)\end{array}$ & $\begin{array}{c}190.00 \pm 10.11 \\
(7.82 \%)\end{array}$ & $\begin{array}{c}222.00 \pm 10.43 \\
(18.16 \%)\end{array}$ & $\begin{array}{c}278.29 \pm 13.03 \\
(31.94 \%)\end{array}$ \\
\hline $6(750 \mathrm{mg} / \mathrm{kg}$ of ESL) & $\begin{array}{c}173.14 \pm 10.11 \\
(0 \%)\end{array}$ & $\begin{array}{c}186.64 \pm 12.02 \\
(7.80 \%)\end{array}$ & $\begin{array}{c}217.99 \pm 10.82 \\
(18.11 \%)\end{array}$ & $\begin{array}{c}273.32 \pm 11.81 \\
(31.96 \%)\end{array}$ \\
\hline
\end{tabular}

Values are means \pm SEM. Percentage body weight changes are italicized and bracketed ( ).

ASL=Aqueous extract of Salacia lehmbachii root bark

$\mathrm{ESL}=$ Ethanol extract of Salacia lehmbachii root bark

Table 2. Food intake, water intake and physical toxic sign in control and treated pregnant rats.

\begin{tabular}{|l|l|l|c|c|}
\hline $\begin{array}{c}\text { Study group } \\
\mathrm{n}=15\end{array}$ & $\begin{array}{l}\text { Food intake } \\
\text { (g/day /rat) }\end{array}$ & $\begin{array}{l}\text { Water intake } \\
\text { (ml/day/rat) }\end{array}$ & $\begin{array}{l}\text { Physical sign } \\
\text { of toxicity }\end{array}$ & $\begin{array}{l}\text { Number of maternal } \\
\text { deaths }\end{array}$ \\
\hline Control & $17.76 \pm 1.11$ & $25.10 \pm 3.02$ & 0 & 0 \\
$1(250 \mathrm{mg} / \mathrm{kg}$ of ASL) & $17.86 \pm 1.91$ & $25.21 \pm 2.08$ & 0 & 0 \\
$2(500 \mathrm{mg} / \mathrm{kg}$ of ASL) & $18.69 \pm 2.23$ & $25.19 \pm 1.00$ & 0 & 0 \\
$3(750 \mathrm{mg} / \mathrm{kg}$ of ASL) & $18.96 \pm 3.11$ & $24.94 \pm 2.05$ & 0 & 0 \\
$4(250 \mathrm{mg} / \mathrm{kg}$ of ESL) & $17.77 \pm 1.06$ & $25.09 \pm 2.11$ & 0 & 0 \\
$5(500 \mathrm{mg} / \mathrm{kg}$ of ESL) & $18.66 \pm 2.33$ & $25.00 \pm 3.46$ & 0 & 0 \\
$6(750 \mathrm{mg} / \mathrm{kg}$ of ESL) & $19.01 \pm 1.09$ & $25.24 \pm 1.87$ & 0 & 0 \\
\hline
\end{tabular}

Values are means \pm SEM.

ASL = Aqueous extract of Salacia lehmbachii root bark

$\mathrm{ESL}=$ Ethanol extract of Salacia lehmbachii root bark

Table 3. Implantation indices in Control and treated rats

\begin{tabular}{|l|l|l|l|l|l|l|l|}
\hline $\begin{array}{l}\text { Study group } \\
\mathrm{n}=15\end{array}$ & $\begin{array}{l}\text { No of } \\
\text { Implanta- } \\
\text { tion sites }\end{array}$ & $\begin{array}{l}\text { No of } \\
\text { resorption } \\
\text { sites }\end{array}$ & $\begin{array}{l}\text { No of corpora } \\
\text { Lutea }\end{array}$ & $\begin{array}{l}\text { Implanta- } \\
\text { tion index } \\
(\%)\end{array}$ & $\begin{array}{l}\text { Resorption } \\
\text { index }(\%)\end{array}$ & $\begin{array}{l}\text { Preimplan- } \\
\text { tation loss } \\
(\%)\end{array}$ & $\begin{array}{l}\text { Postimplan- } \\
\text { ation loss }(\%)\end{array}$ \\
\hline Control & $9.01 \pm 0.02$ & $0.00 \pm 0.00$ & $9.27 \pm 0.02$ & $97.17 \pm 3.95$ & $0.00 \pm 0.00$ & $2.81 \pm 1.11$ & $3.77 \pm 0.02$ \\
$1(250 \mathrm{mg} / \mathrm{kg}$ of ASL) & $9.02 \pm 0.01$ & $0.00 \pm 0.00$ & $9.28 \pm 0.02$ & $97.20 \pm 4.01$ & $0.00 \pm 0.00$ & $2.80 \pm 1.18$ & $3.76 \pm 0.08$ \\
$2(500 \mathrm{mg} / \mathrm{kg}$ of ASL) & $9.00 \pm 0.01$ & $0.00 \pm 0.00$ & $9.26 \pm 0.02$ & $97.19 \pm 4.03$ & $0.00 \pm 0.00$ & $2.81 \pm 1.15$ & $3.78 \pm 0.06$ \\
$3(750 \mathrm{mg} / \mathrm{kg}$ of ASL) & $9.01 \pm 0.02$ & $0.00 \pm 0.00$ & $9.27 \pm 0.02$ & $97.20 \pm 3.97$ & $0.00 \pm 0.00$ & $2.81 \pm 1.22$ & $3.77 \pm 0.05$ \\
$4(250 \mathrm{mg} / \mathrm{kg}$ of ESL) & $8.99 \pm 0.01$ & $0.00 \pm 0.00$ & $9.25 \pm 0.02$ & $97.22 \pm 4.00$ & $0.00 \pm 0.00$ & $2.81 \pm 1.01$ & $3.78 \pm 0.02$ \\
$5(500 \mathrm{mg} / \mathrm{kg}$ of ESL) & $9.00 \pm 0.01$ & $0.00 \pm 0.00$ & $9.26 \pm 0.02$ & $97.19 \pm 3.83$ & $0.00 \pm 0.00$ & $2.81 \pm 0.89$ & $3.78 \pm 0.06$ \\
$6(750 \mathrm{mg} / \mathrm{kg}$ of ESL) & $9.01 \pm 0.02$ & $0.00 \pm 0.00$ & $9.27 \pm 0.02$ & $97.20 \pm 4.09$ & $0.00 \pm 0.00$ & $2.80 \pm 0.88$ & $3.77 \pm 0.05$ \\
\hline
\end{tabular}

Values are expressed as mean \pm SEM. $\mathrm{n}=15$

$\mathrm{ASL}=$ Aqueous root bark extract of Salacia lehmbachii

$\mathrm{ESL}=$ Ethanol root bark extract of Salacia lehmbachii 
Table 4. Fetal indices in Control and Treated rats

\begin{tabular}{|l|l|l|l|l|l|}
\hline $\begin{array}{l}\text { Study group } \\
\mathrm{n}=15\end{array}$ & $\begin{array}{l}\text { No. of dead } \\
\text { fetus }\end{array}$ & $\begin{array}{l}\text { No. of live } \\
\text { fetus }\end{array}$ & Fetal weight $(\mathrm{g})$ & $\begin{array}{l}\text { crown rump } \\
\text { length }(\mathrm{cm})\end{array}$ & $\begin{array}{l}\text { Placental } \\
\text { Weight }(\mathrm{g})\end{array}$ \\
\hline Control: & 0 & $8.67 \pm 0.56$ & $2.65 \pm 0.09$ & $3.40 \pm 0.56$ & $0.44 \pm 0.02$ \\
\hline Control & 0 & $8.67 \pm 0.56$ & $2.65 \pm 0.09$ & $3.40 \pm 0.56$ & $0.44 \pm 0.02$ \\
$1(250 \mathrm{mg} / \mathrm{kg}$ of ASL) & 0 & $8.68 \pm 0.02$ & $2.68 \pm 0.15$ & $3.48 \pm 0.02$ & $0.45 \pm 0.01$ \\
$2(500 \mathrm{mg} / \mathrm{kg}$ of ASL) & 0 & $8.66 \pm 0.41$ & $2.79 \pm 0.23$ & $3.52 \pm 0.01$ & $0.48 \pm 0.01$ \\
$3(750 \mathrm{mg} / \mathrm{kg}$ of ASL) & 0 & $8.67 \pm 0.01$ & $2.86 \pm 0.27$ & $3.58 \pm 0.01$ & $0.51 \pm 0.01$ \\
$4(250 \mathrm{mg} / \mathrm{kg}$ of ESL) & 0 & $8.65 \pm 0.42$ & $2.64 \pm 0.16$ & $3.41 \pm 0.03$ & $0.44 \pm 0.01$ \\
$5(500 \mathrm{mg} / \mathrm{kg}$ of ESL) & 0 & $8.66 \pm 0.68$ & $2.61 \pm 0.05$ & $3.39 \pm 0.04$ & $0.41 \pm 0.01$ \\
$6(750 \mathrm{mg} / \mathrm{kg}$ of ESL) & 0 & $8.67 \pm 0.53$ & $2.28 \pm 0.03 *$ & $3.13 \pm 0.02^{*}$ & $0.26 \pm 0.02 *$ \\
\hline
\end{tabular}

Values are expressed as mean \pm SEM. $\quad \mathrm{n}=15$

* Significant compared to control at $\mathrm{p}<0.05$

ASL and ESL $=$ Aqueous and ethanol root bark extracts of Salacia lehmbachiirespectively

\section{Discussion}

Fetal development is a highly organized process in which complex changes are coordinated sequentially in time, and changes at the molecular and cellular levels are integrated to enable manifestation of a particular phenotype in the whole organism. Maternal homeostasis contributes significantly to fetal development and is assessed using some maternal parameters (body weight changes, food and water intake) and clinical signs of toxicity (salivation, diarrhea, behavioural changes and vaginal bleeding) during pregnancy $[35,39,40]$. Usually, increase in maternal body weight accompanies pregnancy, so the observation of such increase in the dams in this study was an indication that they were actually pregnant. Ekhator and Shelu [41] while evaluating the abortificient potentials of the unripe seed extract of Carica papaya used increase in maternal mean body weight of rats as a sign and progress of pregnancy. Since literature search shows no previous work on the effect of Salacia lehmbachii on pregnancy and fetal development, there are no results on the plant to compare with findings of this work. However, effects of Salacia reticulata, a specie in the genus, Salacia and some other herbs on pregnancy and fetal development have been evaluated [35, 40-46].

It has been established that a correlation exists between maternal toxicity and developmental toxicity [47]. The lack of maternal toxicity in this study as avidenced by absence of maternal deaths and clinical signs of toxicity as well as the similarity in food and water intake in all experimental groups suggests that the extracts do not cause developmental toxicity. Similar results were obtained from the root extract of S. Reticulata and extract of the aerial parts of Mentha piperita [42,43].

Implantation of the fertilized egg is a critical step of conception and the conception index correlates with the site of implantation and the number of corpora lutea [44]. The implantation index and pre-implantation loss rate evaluate blastocyst implantation in the uterus while the resorption index and post-implantation loss rate establish correlation between the number of implanted blastocysts and those that have not developed [35,41]. The absence of statistical difference in the implantation index, pre-implantation and post-implantation losses between treated and control rats as observed in this study is an indication that the numbers of blastocysts implanted were within normal range. The absence of abortions in the experimental groups agrees with the observed nil value of resorption index and suggests normal development of the implanted blastocysts. Normal implantation was also reported in pregnant rats treated with Carapa quianensis seed oil and aqueous stem extract of Bulbine natalensis Baker $[48,45]$. On the contrary, there was impaired embryo development in rats treated with the root extract of $S$. reticulata because of post-implantation losses, and those given extracts of Asparagus racemosus and Solanum lycocarpum as a result of increased number of resorptions [42, 46, 44].

The weights and crown rump lengths of litters and placental weights are known indicators of fetal development [49]. Birth weight is thus a reflection of intrauterine fetal growth which is also determined by factors like the amount of nutrients from the mother and the transporting capacity of such nutrients to the fetus by the placenta. Inhibition of fetal growth in vivo may thus manifest as a reduction in mean fetal weight, crownrump length, and placental weight [44]. As an earlier study had shown the ASL extract to stimulate erythrocytosis [32], the slight increase in fetal weight, crown rump length and placental weight observed in the rats treated with ASL may be speculated to be from a positive nutritional effect of the extract. Further studies will however be required to verify this position. A reduction in the fetal parameters as mentioned, at a high dose $(750 \mathrm{mg} / \mathrm{kg})$ of ESL suggests a potential embryotoxic effect. Similar dose dependent embryotoxic potential was observed with the aqueous stem extract of Bulbine natalensis Baker [45]. Furthermore, the absence of physical abnormalities in the fetuses and placentas with both ASL and ESL indicates there is no teratogenicity from the extracts at the doses studied. Lack of teratogenic effects was also reported with the root extract of Salacia reticulata [42]. 


\section{Conclusion}

Findings from this study show that the aqueous and ethanol extracts of root bark of Salacia lehmbachii at the doses used are not embryotoxic and donot have terratogenic action. However, usage of the ethanol extract at doses higher than $750 \mathrm{mg} / \mathrm{kg}$ should be avoided in pregnancy as there was a reduction in fetal indices at that dose.

\section{Acknowledgements}

The authors are grateful to Mr. Marcus Inyang and other laboratory staff of Department of Pharmacology and Dr. Mrs. A. O. Akpantah of Anatomy Department, University of Calabar, Calabar for technical assistance.

\section{References}

[1]. World Health Organization, 2008. Traditional medicine. Geneva. Available from: http://www.who.int/medicines/areas/ traditional/en/ [Accessed 11 May 2016].

[2]. J Barnes, Quality, efficacy and safety of complementary medicines: fashions, facts and the future. Part1Regulation and quality, British Journal of Clinical Pharmacology 55(3), 2003, 226-233.

[3]. L. Cuzzolin and G. Benoni, Safety issues of phytomedicine in pregnancy and pediatrics in K.J. Ramawat (Ed.), Herbal Drugs, Ethnomedicine to Modern Medicine. (Germany, Springer- Verlag, 2009).

[4]. A. K. Drew, Safety issues in herbal medicine: implication for the health profession, Medical Journal of Australia 166, 1997, 538541.

[5]. M. Roulet, R. Laurini, L. Rivier and A. Calame, Hepatic veno-occlusive disease in newborn infant of a woman drinking herbal tea, Journal of Pediatrics, 112, 1988, 433-436.

[6]. T. G. Saxe, Toxicity of medicinal herbal preparation, American Family Physician, 35, 1987, $135-142$.

[7]. G. Holcberg, M. Tsadkin-Tamir, O. Sapir, H. Mahmoud, M. Moshe and Z. Ben, New Aspects in Placental Drug Transfer, The Israel Medical Association Journal, 5, 2003, 873-876.

[8]. R Loebstein, A. Lalkin and G. Koren, Pharmacokinetic changes during pregnancy and their clinical relevance, Clinical Pharmacokinetics, 33(5), 1997, 328-343.

[9]. M.M. Costantine, Physiologic and pharmacokinetic changes in pregnancy. Frontiers in Pharmacology, 5(65), $2014,1-5$.

[10]. W. G. McBride, Thalidomide and congenital abnormalities (letter), Lancet, 2, 1961, 1358.

[11]. W. Lenz, Thalidomide and congenital abnormalities (letter), Lancet, 1, 1962, 45.

[12]. G. W. Mellin and M. Katzenstein, Medical progress: the saga of thalidomide (concluded). Neuropathy to embryopathy, with case reports of congenital anomalies, New England Journal of Medicine, 267, 1962, 1238-1245.

[13]. J. Gold and W. Cates, Herbal abortifacients. Journal of American Medical Association, 243, 1980, $1365-1366$

[14]. D. Nath, N. Sethi, R. K. Singh and A. K. Jain, Commonly used Indian abortifacient plants with special reference to their teratologic effects in rats, Journal of Ethnopharmacology, 36(2), 1992, 147-154.

[15]. Chaudhury, M.R., Chandrasekaran, R. and S. Mishra, 2001. S. Embryotoxicity and teratogenicity studies of an ayurvedic contraceptive-pippaliyadi vati. Journal of Ethnopharmacology, 74(2), 2001,189-193.

[16]. H. Han, H. Saing, A.C.H. Choi and J.M. Nicolls, A girl with a perineal phallic mass. British Journal of Urology, 80, $1997,962-963$.

[17]. M. Roulet, R. Laurini, L. Rivier and A. Calame, Hepatic veno-occlusive disease in newborn infant of a woman drinking herbal tea. Journal of Pediatrics, 112, 1988, 433-436.

[18]. A. Takei, G. Nagashima, R. Suzuki, H. Hokaku, M. Takahashi, T. Miyo, J. Asai, Y. Sanada and T. Fujimoto, Meningoencephalocele associated with Tripterygium wilfordii treatment, Pediatrics and. Neurosurgery, 27, 1997, 45- 48.

[19]. M. Gallo, M. Sarkar, W. Au, K. Pietrzak, B. Comas, M. Smith, T. V. Jaeger, A. Einarson and G. Koren, Pregnancy outcome following gestational exposure to echinacea: a prospective controlled study, Archives of Internal Medicine, 160, $2000,3141-3143$.

[20]. M. H. Mabina, S. B. Pitsoe and D. Moodley, 1997. The effect of traditional herbal medicines on pregnancy outcome. The King Edward VIII Hospital experience, South African Medical Journal, 87, 1997, 1008- 1010.

[21]. K.C.S. Costa, S.B. Bezerra, C. M. Norte, L.M.N. Nunes and T.M. Olinda, Medicinal plants with teratogenic potential: current considerations. Brazilian Journal of Pharmaceutical Sciences, 48(3), 2012, 427-433.

[22]. C. N. Ekhator and U.C. Osifo, 2015. Abortifacient Efficacy of Moringa oleifera Leave: An Experimental Study on Adult Female Wistar Rats, American Journal Biology and Life Sciences, 3(6), 2015, 269-272.

[23]. M. Desai, F.O. ter Kuile, F. Nosten, R. McGready, K. Asamoa, B. Brabin and R.D Newman, Epidemiology and burden of malaria in pregnancy, Lancet Infectious Diseases, 7(2), 2007, 93-104.

[24]. L. P. Takem, B.A.S. Lawal, and P. M. Udia, Analgesic and Acute Anti-inflammatory Activities of Aqueous Root Extract of Salacia lehmbachii, British Journal of Pharmacological Research, 4(18), 2013, 2172-2181.

[25]. A. D. Essien, G. C. Akuodor, A. E. Edidara, E. C. Asika, K. C. Chilaka and S.K. Nwadum, Evaluation of Antipyretic Potential of the Ethanolic Leaf Extract of Salacia lehmbachii Loes, Asian Journal of Medical Sciences, 7(2), 2015, 22-25.

[26]. A. D. Essien, L.P. Takem and P. M. Udia, Role of Salacia lehmbachii extract in renal function, International Journal of Pharmacology and Pharmaceutical Sciences, 2 (1), 2015, 23-28.

[27]. L.P. Takem, B.A.S Lawal, F.V. Udoh and N.P. Abe, Anti-Abortifacient Activities of Aqueous Root Extract of Salacia lehmbachii in Wistar Rats, Journal of Pharmacology and Pharmaceutical Sciences, 1(3), 2014, 195-199.

[28]. W. N. Okechi, B.A.S. Lawal, N. P. Wokota and J. Hassan, Evaluation of in-vivo and in-vitro antioxidant activities of methanol extract of Salacia lehmbachii Loes leaf, European Journal of Medicinal Plants, 8(4), 2015, 214-223.

[29]. G. A. Essiet, A.D. Essien, G. C. Akuodor, F. V. Udoh and A. Essiet, Effect of Ethanol extract root bark of Salacia lehmbachii Loes on male reproductive hormones in albino rats, European Journal of Medicinal Plants, 15(3), 2016, 1-7.

[30]. G. A. Essiet, A.D. Essien, G. C. Akuodor, F. V. Udoh and A. Essiet, Anti-fertility Effects of Ethanol Extract of Salacia lehmbachii Root Bark in Albino Rats, Journal of Advances in Pharmaceutical Sciences, 8(4), 2016, 1-8.

[31]. G. A. Essiet, L. P. Takem, A.D. Essien, G. C. Akuodor, F. V. Udoh and A. Essiet, Evaluation of Hepatic Toxicity of Salacia lehmbachii. International Journal of Pharmacology and Pharmaceutical Sciences, 6 (2), 2016, 95-103.

[32]. G. A. Essiet, L. P. Takem, A.D. Essien, G. C. Akuodor, F. V. Udoh, Assessment of Haematopoietic Toxicity of Salacia lehmbachii. International Journal of Pharmacology and Pharmaceutical Sciences, 'in press'. 
[33]. Organization for Economic Co-operation and Development (OECD), Guidance Document on the Recognition, Assessment, and Use of Clinical Signs as Humane Endpoints for Experimental Animals Used in Safety Evaluation. The Animal Welfare Information Center Bulletin (AWIC) Bulletin, 11(1-2), 2000, 1-27.

[34]. O. Oderinde, C. Noronha, A. Oremosu, T. Kusemiju and A. Okanlawon, Abortifacient properties of Aqueous extract of Carica papaya (Linn) seed on female Sprague- Dawley rat, Nigerian Postgraduate Medical Journal, 9 (2), 2002, 95-98.

[35]. F.C.G. Almeida and I. P. Lemonica, The toxic effects of Coleus barbatus B. on the different periods of pregnancy in rats. Journal of Ethnopharmacology, 73, 2007, 53-60.

[36]. R.G. York, R. M. Parker and L. T. Haber, Test methods for assessing female reproductive and developmental toxicology, in A. W. Hayes (Ed.), Principles and methods of toxicology, 6 (New York: Raven Press, 2014) 1637-1722.

[37]. M. Fujinaga and R.I. Mazze, Teratogenic and postnatal developmental studies of morphine in Sprague-Dawley rats, Teratology, 38(5), 1988, 401-410.

[38]. P. J. Vento, M. E., Swartz, L.B.E. Martin and D. Daniels, Food Intake in Laboratory Rats Provided Standard and Fenbendazolesupplemented Diets. Journal of American Association of Laboratory Animal Science, 47(6), 2008, 46-50.

[39]. N.F. Butte, W. W. Wong, M. S. Treuth, K. J. Ellis and E.O.A. Smith, Energy requirements during pregnancy based on total energy expenditure and energy deposition, American Journal of Clinical Nutrition, 79(6), 2004, 1078-1087.

[40]. M. Guerra, A. S. B. Mazoni, M. A. F Brandao and V.M. Peters, Toxicology of lapachol in rats: Embryolethality, Reviews in Brazilian Biology, 61, 2000, 71-174.

[41]. C. N. Ekhator and J. O. Shelu, An Experimental Study on the Abortificient Potentials of Unripe Seed Extract of Carica papaya in Adult Female Wister Rats, Open Science Journal of Pharmacy and Pharmacoogy, 3(6), 2015, 61-65.

[42]. W. D. Ratnasooriya, J. R. Jayakody and G. A. Premakumara, Adverse pregnancy outcome in rats following exposure to a Salacia reticulata (Celastraceae) root extract, Brazilian Journal of Medicine and Biological Research.,36(7), 2003, 931-935.

[43]. M.J. Golalipour, . Ghafari, A. Maleki, M. Kiani, E. Asadi and M. Farsi, Study of Embryotoxicity of Mentha piperita L. during organogenesis in Balb/c mice. International Journal of Morphology, 29(3), 2011, 862-867.

[44]. C. V.Chang, A. C. Felicio, J.E.P. Reis, M.O. Guerra and V.M. Peters, Fetal toxicity of Solanum lycocarpum (Solanaceae) in rats, Journal of Ethnopharmacology, 81, 2002, 265-269.

[45]. M.T. Yakubu and A.J. Afolayan, Reproductive toxicologic evaluations of Bulbine natalensis Baker stem extract in albino rats, Theriogenology, 72, 2009, 322-332.

[46]. R. K. Goel, T. Prabba, M. M. Kumar, P. S. Dorababu and G. Singh, Teratogenicity of Asparagus racemosus Willd. roots, a herbal medicine, Indian Journal of Experimental Biology, 44, 2006, 570-573.

[47]. H. Ema, R. Kurosaka, A. Harazono, H. Amano and Y. Ogawa, Phase specificity of developmental toxicity after oral administration of mono-n-butyl phthalate in rats. Archives of Environmental Contamination and Toxicology, 31, 1996, $170-176$.

[48]. W, C, L. Ford, The effect of 6- deoxy-6 fluoroglucose on the fertility of male rat and mice. Contraception, 25(5), 1982, 534-543.

[49]. C. Mayer and K. S. Joseph, Fetal growth: a review of terms, concepts and issues relevant to obstetrics, Ultrasound Obstetrics and Gynecology, 41, 2013, 136-145. 